\title{
Advanced Motion as a Hybrid System
}

\author{
Tatsuya Suzuki Member (Nagoya University, t_suzuki@nuem.nagoya-u.ac.jp)
}

Keywords: hybrid dynamical system, advanced complex motion, parameter estimation, symbolic grounding

Recently, the demand for motion control systems is shifting from the realization of high performance to the development of humanfriendly control systems. This implies that the emphasis is shifting toward design of motion control systems that meet each customer's specific requirements. Although considered important, this matter has not yet been addressed entirely due to the wide variety of customer demands. To formally address this problem, it is necessary to develop a mathematical model of the complex motion of different operators and to exploit it to design a control system. This viewpoint is of particular importance when the elderly and/or the disabled person are involved in the system.

Due to the abovementioned circumstances, human motion modeling has attracted much attention from several researchers. In order to model human motion, the conventional techniques such as the nonlinear regression models, neural networks and fuzzy systems have been used. The usage of these techniques, however, pose certain problems: (1) the obtained model is often too complicated and (2) this, in turn, makes it impossible to understand the physical meanings of the operator's manipulation. When we consider human motion, it is often found that a operator appropriately switches between certain simple primitive motions instead of adopting a complex nonlinear control law. This switching between primitive motions can be caused by the operator's decision-making process and/or the change of the environmrnt. This consideration strongly motivates us to model the complex human motion as a hybrid dynamical system (HDS) as shown in Fig. 1. HDSs comprise both continuous dynamics and discrete mode changes. The former are typically associated with differential (or difference) equations and the latter with automata, logic, etc. By regarding the operator's primitive motions and switching scenario as the continuous and discrete parts of an HDS, respectively, the understanding of the human motion can be recast as a parameter estimation problem in the HDS framework. In control and computer science communities, many studies have reported on the expression, stability analysis, control, verification, and identification of the HDSs. However, the application of the HDS model to the analysis of human motion has not yet been fully discussed. The advantages of motion modeling based on the hybrid dynamics are: (1) The complex dynamical behavior can be represented by underlying some primitive dynamics together with switching mechanism between them. (2) The obtained model could be useful for various application, such as, design of assist controller, recognition of the human motion, and so on.
This paper presents a modeling and analysis strategy of complex human motion based on a HDS framework. In particular, the modeling and analysis problem of human motion is addressed as a parameter estimation problem of the piecewise ARX (PWARX) model. The PWARX model is one of the classes in the HDSs, and can be broadly classified into two subclasses: The first subclass is the PWARX models wherein the transition between discrete states (modes) is specified in terms of deterministic logic, which is give by the following form:

$$
\left\{\begin{array}{clll}
y_{k}=\boldsymbol{\psi}_{k}^{T} \boldsymbol{\theta}_{1}+e_{1, k}, & \text { if } \quad \boldsymbol{\psi}_{k} \in C_{1} & \text { (Mode 1) } \\
y_{k}=\boldsymbol{\psi}_{k}^{T} \boldsymbol{\theta}_{2}+e_{2, k}, & \text { if } \quad \boldsymbol{\psi}_{k} \in C_{2} & (\text { Mode 2) } \\
\vdots & & & \\
y_{k}=\boldsymbol{\psi}_{k}^{T} \boldsymbol{\theta}_{N}+e_{N, k}, & \text { if } & \boldsymbol{\psi}_{k} \in C_{N} & (\text { Mode N) }
\end{array}\right.
$$

The second one is the PWARX models wherein the transition is specified by transition probabilities, which can be regarded as an extension of the standard hidden markov models. The outline of parameter estimation for both subclasses are briefly reviewed in this paper. Then, the parameter estimation for the deterministic PWARXs is applied to a driver's vehicle following task. Also, the parameter estimation for the stochastic PWARXs is applied to a pegin-hole task. These two applications represent two typical classes of the advanced complex human motion. The obtained results show the high potential ability of the HDSs for representing complex human motion.

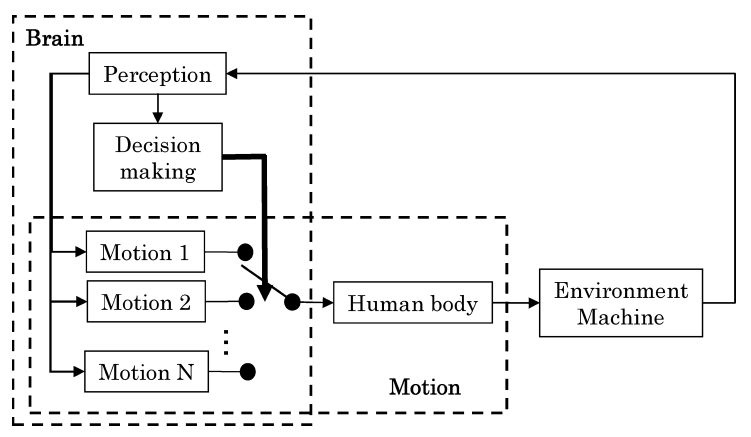

Fig. 1. Advanced motion as a hybrid system 


\title{
ハイブリッドシステムと高次モーション
}

\author{
正 員 鈴木 達也*
}

\author{
Advanced Motion as a Hybrid System
}

Tatsuya Suzuki*, Member

\begin{abstract}
This paper presents a modeling and analysis strategy of advanced complex human motion based on a hybrid system framework. The motion modeling problem is addressed as a parameter estimation problem of the piecewise ARX model which is a class of the hybrid dynamical systems. The advantages of motion modeling based on the hybrid dynamics are: (1) The complex dynamical behavior can be represented by underlying some primitive dynamics together with switching mechanism between them. (2) The obtained model could be useful for various application, such as, design of assist controller, recognition of the human behavior, and so on. Finally, the developed strategy is applied to a driver's vehicle following task and a peg-in-hole task which represent two typical classes of the complex human motion. The obtained results show the usefulness of the hybrid dynamics for representing complex human motion.
\end{abstract}

キーワード：ハイブリッドシステム, 高次モーション, パラメータ推定, 記号接地

Keywords: hybrid dynamical system, advanced complex motion, parameter estimation, symbolic grounding

\section{1. はじめに}

人間行動モデルの構築は, 人間と共存する人工物の設計 において不可欠の重要な課題である。高次の人間行動は, 通常, 「認知」,「判断」,「動作」の各プロセスを経て発現す ると考えられているが，このような高次の人間行動をモデ ル化するためには, 各プロセスを個別に切り出してモデル 化・解析するだけでは不十分であり，それらの相互作用ま で考慮に入れる必要がある。そのためには，これらをでき るかぎり統一的に扱う枠組みが必要となるが，これまで，こ れらを統一的に捉えた例はあまりない。これは，高次の人 間行動における「判断」が「する」か「しない」かの離散 的な（二值的な）情報処理であるのに対して，認知系にお ける処理や動作系における動特性が連続的な情報処理であ ることから，適切な統一的数理表現が欠落していたことが 要因の一つであると考えられる。

一方, 複雑な環境に対して人間が見せる高度なスキルに おいては，巧みに「モード遷移」を引き起こしながら，複雑 な環境に適応している例を良く見かける。スキルにおいて 見られる「モード遷移」は通常, 無意識のうちに（環境に 適応する形で自発的に）起こるモード遷移と考えられるの に対し，上述の高次の人間行動における「判断」は一種の

\footnotetext{
名古屋大学

干 464-8603 名古屋市千種区不老町

Nagoya University

Furo-cho, Chikusa-ku, Nagoya 464-8603
}

意図的なモード遷移と解釈することができる。いずれにし ても, モード遷移はシステム論的には離散的な情報処理で あることから, やはり, 連続系と離散系の混在した統一的 な数理表現が必要となってくる。本論文では，このような 高次の人間行動や高度なスキルを総称して「高次モーショ ン」と呼ぶことにする。

以上を踏まえて本論文では，「人間が見せる高次モーショ ンは, 一連のプリミティブな動作とその切り替え (判断) に よって実現される」との考え方に立って, 連続/離散ハイ ブリッドシステム（例えば，文献 (1)）の観点から高次モー ションの解析・設計のための新たな枠組みを提案し(2) (9), その有用性と今後の可能性について論じる。本論文では特 に, 高次の人間行動や高度なスキルの具体例として, 前方 車追従運転 ${ }^{(7)}$ とぺグ挿入作業 ${ }^{(8)}$ をそれぞれ取り上げ，ハイ ブリッドシステムとして捉えることの有用性を示す。

本論文で提案する枠組みの基本的な戦略は, 観測された モーションデータに対して，ハイブリッドシステムに対す るパラメータ推定手法を適用し, プリミティブな動作とモー ド遷移を観測データから同時にモデル化するというもので ある。ここで得られる高次モーションのモデルは, 一見す ると複雑に見える高次モーションを, いくつかの動作モー ドの集合とその切り替えで表現することにより，(1)物理的 理解が容易, (2) 計算コストが少ない, (3) 表現能力が高い, モデルとなっている。結果として, 高次モーションに対す る実時間予測やアシスト系の設計等の工学的利用につなげ やすいモデルであるという特長を有することから，ハイブ 
リッドシステムとして高次モーションを捉える試みは，高 次モーションをモデル化, 解析, 設計するための基本的な 枠組みを提供することになると期待される。

\section{2. ハイブリッドシステムと高次モーション}

図 1 に本論文で提案する高次モーションモデルの概略を 示す。図 1 において, ‘Perception’ は「知覚（情報の取捨 選択，加工)」を， 'Decision making’は「判断」あるいは 「モード遷移」を，また，'Motion’は脳内で生成される「動 作モード」を表しており，いくつかの異なったモードがある と仮定する。最終的には，脳から出力される指令に基づい て，手足が動作し，ある夕スクを遂行する。図 1 に示すモ デルでは，「動作モード」は知覚情報に対してある連続的な 情報処理を行うのに対し,「判断」は，いくつかの動作モー ドの選択・切り替え，つまり離散的な情報処理を行ってい ることになる。このように，タイプの異なる情報処理をハ イブリッドダイナミクスの観点から明示的に混在させてい る点が従来のモデルと比べた場合のこのモデルの大きな特 徵である。

ハイブリッドシステムに対する研究が盛んになってきた のは 90 年後半からであるが，プリミティブな動作の合成に 基づく行動モデルの考え方の起源も同時期であり，神経科 学分野における E. Bizzi らによる研究 ${ }^{(10)(11)}$ やパターン認 識分野における C. Bregler ら ${ }^{(12)}$ や L. Goncalves ら ${ }^{(13)}$ の研 究に見ることができる。これらの研究に共通している点は, とりもなおさず，人間が見せる複雑な高次モーションはプ リミティブな動作の（広い意味での）合成により表現され る，としている点である。プリミティブな動作の合成方法 は，単純な線形和や，順序結合や並列結合といった組み合わ せ結合的なものまで様々な可能性が考えられるが，観測さ れたモーション全体の特徵を捉える数理モデルの構築，お よびその工学的利用を考えると，特に順序関係を伴った結 合関係の抽出が重要になると思われる。このことは，モー ションをいくつかの動作モードの一連のつながりで表現す ることを意味するが，このようにモーションを捉える例を 以下にいくつか示す。例えば，歩行運動は接地，非接地の

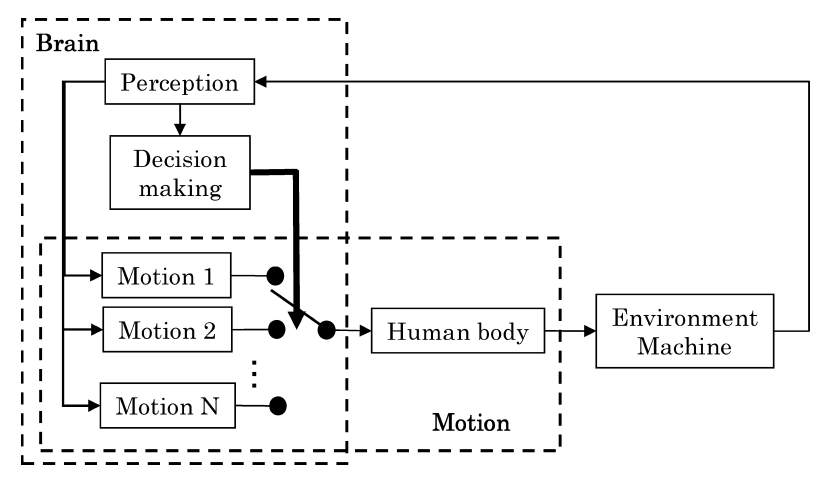

図 1 ハイブリッドシステムとしての高次 モーション

Fig. 1. Advanced motion as a hybrid system.
状態に応じて「左脚遊脚 - 右脚接地」「两脚接地 (左脚前)」 $\lceil$ 左脚接地・右脚遊脚」「両脚接地 (右脚前)」といった区分 動作の繰り返しと解釈することができる ${ }^{(4)}$ 。また, 環境と の接触状態が時々刻々変化する peg-in-hole 作業や把握作業 においては，環境の変化から引き起こされる無意識のモー ド遷移が存在すると考えられる ${ }^{(8)}$ 。また，低速歩行から高 速歩行への切り替えや, 障害物回避動作, あるいは自動車 等の運転行動等においては, 目標とするタスクの遂行状況 に応じて人間が意図的にモードを切り替えていると考えら れる (5) (7)。さらには，体の一部に不具合 (故障) が発生し た場合にもやはりそれをリカバーすべく必要なモード遷移 を行っていると考えられる。このように非常に幅広い高次 のモーションに対してハイブリッドシステムとしての解釈 が可能である。

本論文では，以下，観測されたモーションデータに対し てハイブリッドシステムのパラメータ推定手法を

導入することで高次モーションを解析・モデル化する手 法について具体例を交えて論じる。

\section{3. ハイブリッドシステムのパラメータ推定}

ハイブリッドシステムに対するパラメータ推定法はさま ざまな形で提案されているが，大きく分けてモード（離散 状態）の遷移が確定的な場合 ${ }^{(15) \sim(19)}$ と, 確率的な場合 ${ }^{(20) \sim(22)}$ とで異なる。以下に, 本研究で用いたデータクラスタリン グに基づいたアプローチ(17) と EM アルゴリズムに基づい たアプローチ ${ }^{(22)}$ の概要を述べるが，これらの詳細や他の手 法については紙面の都合上，各文献を参照されたい。

〈3・1〉 データクラスタリングを用いた確定的ハイブリッ ドシステムのパラメータ推定（1)式に示すような $N$ 個の モードからなる区分的 ARX モデル (PWARX : PieceWise AutoRegressive eXogenious model）を考える。(1) 式にお いて， $k$ は離散時刻を表し， $y_{k}$ は時刻 $k$ での出力を表す。 また， $\psi_{k}$ は時刻 $k-1$ 以前の入出力データから構成される regressor ベクトルであり, $\boldsymbol{\theta}_{i}$ は第 $i$ モードのダイナミクスに 関するパラメータベクトルを表す。このモデルは, regressor ベクトルの存在領域によってモード（ダイナミクス）が切 り替わるタイプのハイブリッドシステム表現となっている。 また, $e_{i, k}$ はモードごとに異なる式誤差であり, 白色性と仮 定する。

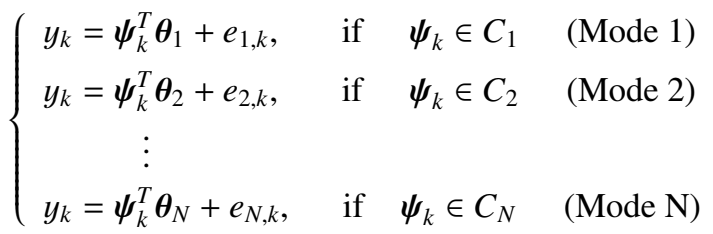

データクラスタリングを用いた確定的ハイブリッドシステ ムのパラメータ推定 ${ }^{(17)}$ の基本的アイデアは，まず，局所ダ イナミクスを特徴量としたクラスタリング手法を用いて各 データの属するモードを決定し，そのあとで Support Vector Machine (SVM) 等を用いて各モード間の分離面を求める 


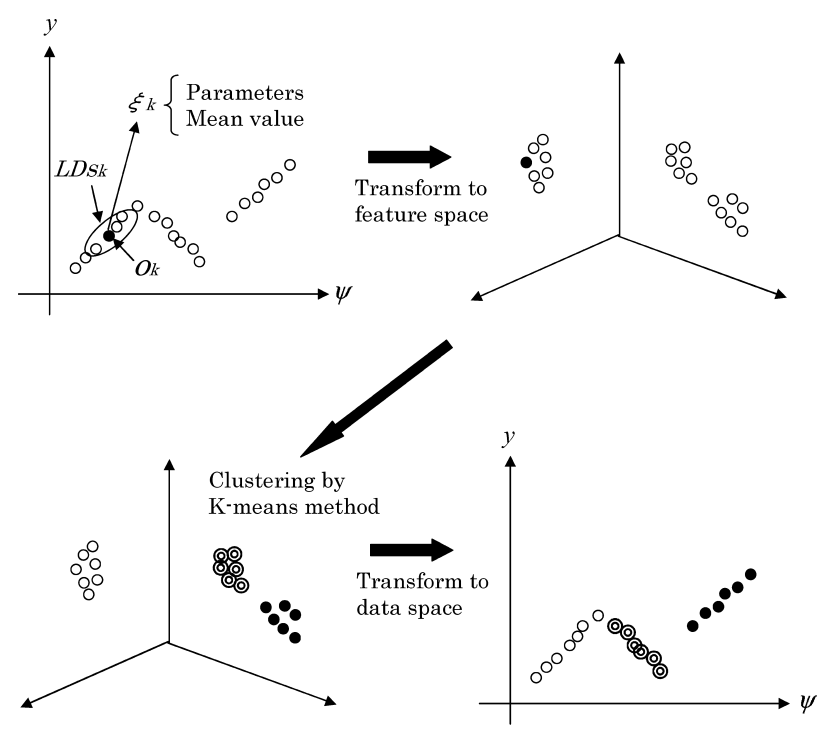

図 2 クラスタリングを用いたモード分割の概要

Fig. 2. Outline of mode segmentation based on a clustering.

という点にある。クラスタリング手法は比較的大量のデー 夕を扱うことが可能なため，モーションの解析のように大 量のデー夕を扱う必要がある問題に対しても実用性は高い と言える。以下にその概要を示す（図 2 参照; ただし，図 2 において は一次元としている)。

まず準備として，時刻 $k$ での観測データ $o_{k}$ を以下のよう に定義する。

$$
o_{k}=\left(y_{k}, \psi_{k}\right) \quad(k=0,1 \ldots, T)
$$

- 入出力からなるデータ系列 $\boldsymbol{O}=\left(o_{0}, \ldots, o_{T}\right)$ が得られ た場合，図 2(a)のように各 $o_{k}(k=0,1 \ldots, T)$ に対し 距離の近い $c$ 個のデー夕を集め局所集合 $L D s_{k}$ を作り, 特徵量 $\xi_{k}$ を求める。ここで, 特徵量 $\xi_{k}$ は $L D s_{k}$ 中の データに対して ARX モデルを当てはめ, 最小二乗推 定を施すことにより得られるパラメータ（(1) 式中の $\theta_{i}$ に相当）と $L D s_{k}$ 中のデータの平均值とから構成さ れる。

・デー夕系列 $\boldsymbol{O}$ 中の各デー夕 $o_{k}(k=0,1 \ldots, T)$ を特徵 量 $\xi_{k}$ に変換することで特徵空間における分布を得る (b) ((b) では，特徵空間は三次元としている)。そし て，特徵空間上のデータに対し，K-means 法に基づい てクラスタリングを行う (c)。

・特徵空間におけるクラスタリング結果を元のデータ系 列 $\boldsymbol{O}$ に割り当てる $(\mathrm{d})$ 。

クラスタリングされたデータ系列 $\boldsymbol{O}$ 中の各モードに対し, 通 常の最小二乗推定を施すことで各モードにおけるパラメー 夕を求める。

なお，上記の方法の場合，同時に複数本のデータ系列を 解析対象としても何ら問題はない。ただし，K-means 法は 基本的にはひずみ誤差を極小化するクラスタリング手法で

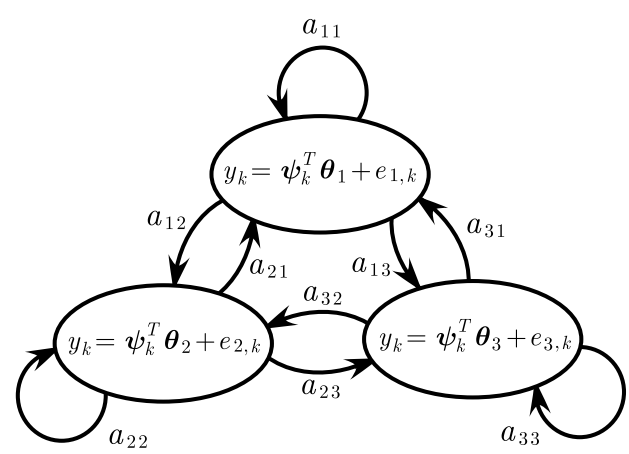

図 3 確率的切り替えを伴うPWARX モデル

Fig. 3. Stochastic switched PWARX model.

あるため，常に最適なクラスタリング結果が得られるとは 限らない。したがって本研究では, 初期参照べクトルの配 置を変更しながらクラスタリングを行った。

次に切り替え条件の推定であるが，モード分割（クラス タリング）がすでになされているので，各クラス夕間の分 離面を求めることで，モードの切り替え条件が求められる。 データが十分多ければ，例えば SVM 等を適用することで， 非線形な分離面を含めたより一般的な切り替え条件（分離 面）を推定することも可能である。

〈3・2〉確率的ハイブリッドシステムのパラメータ推定 図 3 に示すような各モード (離散状態)にそれぞれ異なる ARX モデルが割り当てられ（図 3 ではモード数は 3 として いる), かつモードの遷移が確率的に引き起こされるモデル を考える。図 3 において, 各モードに割り当てられる動的 モデルは(1) 式中の ARX モデルと同じであるが，モード間 の遷移が条件ではなく, 確率值で与えられている点が確定 的なモデルとの違いである。このようなモデルのパラメー 夕推定法は隠れマルコフモデル (Hidden Markov Model : HMM) (20)におけるパラメー夕推定法を拡張することで得 ることができる(22)。以下にその概要を示す。

〈3・2・1〉 パラメータの定義モードの数を $N$ とする と, 推定対象となるパラメータは以下のようになる。 $a_{i j}$ ：モード遷移確率 $(i=1, \cdots, N ; j=1, \cdots, N)$,

$a_{i j}$ はモード $S_{i}$ から $S_{j}$ への遷移確率

$\pi_{i}$ : 初期モード確率 $(i=1, \cdots, N), \pi_{i}$ は時刻 $k=0$ で, モード $S_{i}$ をとる確率

$\boldsymbol{\theta}_{i}$ ：各モード $S_{i}$ での線形モデルのパラメータベクトル $(i=1, \cdots, N)$

$\sigma_{i}$ : 各モード $S_{i}$ に割り当てられた線形モデルの式誤差を 表すガウス分布の分散 $(i=1, \cdots, N)$

ここで, 式誤差 $e_{i, k}$ は白色性と仮定しているが，モードご とに分散が異なるとする(平均值はいずれも零とする)。こ のとき，(2) 式で定義された観測データ $o_{k}$ のモード $i$ にお ける生起確率 $b_{i}\left(o_{k}\right)$ は, 次のように与えられる。

$$
b_{i}\left(o_{k}\right)=\frac{1}{\sqrt{2 \pi} \sigma_{i}} \exp \left\{-\frac{\left(\boldsymbol{\psi}_{k}^{T} \boldsymbol{\theta}_{i}-y_{k}\right)^{2}}{2 \sigma_{i}^{2}}\right\} \ldots \ldots \ldots
$$


このように定義することで EM アルゴリズムに基づいた連 続型 HMM のパラメータ推定と同様な形でパラメータの推 定アルゴリズムが導出できる。

〈3·2・2〉 パラメータの最尤推定 前節で定義したパ ラメータの組を入し，EMアルゴリズムを用いた最尤推定 によりパラメータ入は以下のように推定される。

まずはじめに, 後で必要となる前向き確率 $\alpha(i, k)$ と, 後 ろ向き確率 $\beta(i, k)$ を以下のように定義する。今, 観測でき ないモード遷移系列を $\boldsymbol{s}=\left(s_{0}, s_{1}, \cdots, s_{k}, \cdots, s_{T}\right)$, 観測でき るデー夕系列を $\boldsymbol{O}=\left(o_{0}, o_{1}, \cdots, o_{k}, \cdots o_{T}\right)$ とする。前向き 確率 $\alpha(i, k)$ とは，パラメータが入で与えられるモデルが, 時刻 $k$ までに観測デー夕系列 $\boldsymbol{O}=\left(o_{0}, o_{1}, \cdots, o_{k}\right)$ を出力し て，かつモード $S_{i}$ に達する $\left(s_{k}=S_{i}\right.$ となる）確率である。 また，後ろ向き確率 $\beta(i, k)$ とは，時刻 $k$ でモード $S_{i}$ から $\left(s_{k}=S_{i}\right.$ から $)$, 観測デー夕系列 $\boldsymbol{O}=\left(o_{k+1}, o_{k+2}, \cdots, o_{T}\right)$ を 出力して, 最終モードに達する確率である。従って, 前向 き確率 $\alpha(i, k)$ と, 後ろ向き確率 $\beta(i, k)$ は, 次式のように表 される。

$$
\begin{aligned}
\alpha(i, k)= & \sum_{s_{0}=1}^{N} \sum_{s_{1}=1}^{N} \ldots \sum_{s_{k-1}=1}^{N} \pi_{s_{0}} b_{s_{0}}\left(o_{0}\right) \\
& \times a_{s_{0} s_{1}} b_{s_{1}}\left(o_{1}\right) \times \cdots \times a_{s_{k-1} s_{k}} b_{s_{k}}\left(o_{k}\right), \cdots \cdots \\
\beta(i, k)= & \sum_{s_{k+1}=1}^{N} \sum_{s_{k+2}=1}^{N} \cdots \sum_{s_{T}=1}^{N} a_{s_{k} s_{k+1}} b_{k+1}\left(o_{k+1}\right) \\
& \times a_{s_{k+1} s_{k+2}} b_{s_{k+2}}\left(o_{k+2}\right) \times \cdots \times a_{s_{T-1} s_{T}} b_{s_{T}}\left(o_{T}\right)
\end{aligned}
$$

次に，観測できないモード遷移系列 $\boldsymbol{s}$ と観測できるデー夕 系列 $\boldsymbol{O}$ が生起する尤度 $L(\boldsymbol{s}, \boldsymbol{O} ; \lambda)=P(\boldsymbol{s}, \boldsymbol{O} \mid \lambda)$ を, 最大化

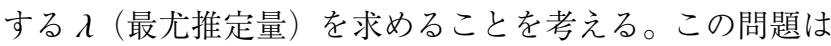
解析的に解くことはできないため, EM (Expectation and Maximization）アルゴリズムを用いる。モード遷移系列が 観測できないことから，EMアルゴリズムではモード遷移 系列に関する観測デー夕系列の尤度の期待值を極大化する ことを考える。具体的には，EMアルゴリズムは次式

$$
\begin{aligned}
Q\left(\lambda, \lambda^{\prime}\right) & =E\left[\log \left\{P\left(\boldsymbol{s}, \boldsymbol{O} \mid \lambda^{\prime}\right)\right\} \mid \boldsymbol{O}, \lambda\right] \\
& =\sum_{s} P(\boldsymbol{s} \mid \boldsymbol{O}, \lambda) \log \left\{P\left(\boldsymbol{s}, \boldsymbol{O} \mid \lambda^{\prime}\right)\right\}
\end{aligned}
$$

で定義される $\mathrm{Q}$ 関数を最大化する $\lambda^{\prime}$ を

（1）適当な初期パラメータ $\lambda$ を定める。

（2） $Q\left(\lambda, \lambda^{\prime}\right)$ を最大化する $\lambda^{\prime}$ を求める。

（3） $\lambda=\lambda^{\prime}$ として収束するまで2.を繰り返す。

に従って逐次的に求める方法である。

EMアルゴリズムを適用することにより，具体的には，次 のような更新則でパラメータを更新する。

$$
\begin{aligned}
\pi_{i}^{\prime} & =\frac{\pi_{i} b_{i}\left(o_{0}\right) \beta(i, 0)}{\sum_{l=1}^{N} \pi_{k} b_{l}\left(o_{0}\right) \beta(l, 0)}, \cdots \ldots \ldots \ldots \ldots \ldots \ldots . . . \\
a_{i j}^{\prime} & =\frac{\sum_{k=1}^{T} \alpha(i, k-1) a_{i j} b_{j}\left(o_{k}\right) \beta(j, k)}{\sum_{l=1}^{N} \sum_{k=1}^{T} \alpha(i, k-1) a_{i l} b_{l}\left(o_{k}\right) \beta(l, k)} .
\end{aligned}
$$

$$
\begin{aligned}
\boldsymbol{\theta}_{i}^{\prime}= & \left\{\sum_{k=0}^{T}\left\{\boldsymbol{\psi}_{k} \boldsymbol{\psi}_{k}^{T} \alpha(i, k) \beta(i, k)\right\}\right\}^{-1} \\
& \times\left\{\sum_{k=0}^{T}\left\{\boldsymbol{\psi}_{k} y_{k} \alpha(i, k) \beta(i, k)\right\}\right\} \ldots \ldots \\
\sigma_{i}^{\prime 2} & =\frac{\sum_{k=0}^{T}\left\{\left|\boldsymbol{\psi}_{k}^{T} \boldsymbol{\theta}_{i}^{\prime}-y_{k}\right|^{2} \alpha(i, k) \beta(i, k)\right\}}{\sum_{k=0}^{T}\{\alpha(i, k) \beta(i, k)\}}
\end{aligned}
$$

(7)〜(10) 式を用いて, EMアルゴリズムにおける3つのス

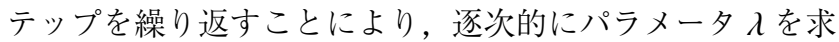
めることができる。

また，モード遷移時刻の推定に関してはViterbi アルゴリ ズム ${ }^{(20)}$ と呼ばれる強力なアルゴリズムがあり, 推定された パラメータを用いて, 最も尤もらしいモード遷移時刻を推 定することが可能である。

\section{4. 確定的ハイブリッドシステムモデルに基づく 前方車追従行動のモデル化}

本章では，認知や判断を伴う高次の人間行動の一例とし て, 高速道路等におけるドライバの前方車追従行動を対象 として, 確定的ハイブリッドシステムモデルに基づいたモ デル化について論じる(7)。ドライバの行動モデリングに関 してはすでに多くの先行研究があるが(23) (26), 本研究の特徴 は，モードとその遷移という概念を明示的に導入してモデ ル化を行う点にある。運転デー夕取得に当たっては立体視 可能なドライビングシミュレータを用い，前方車の速度は $0[\mathrm{~km} / \mathrm{h}]$ から $120[\mathrm{~km} / \mathrm{h}]$ の範囲内で可変とした。このとき 得られた観測デー夕を図 4 に示す。図 4 は, 上から順に, 車間相対速度 $\left(x_{3}\right)$, 車間距離 $\left(x_{2}\right), \mathrm{KdB}\left(x_{1}\right)$, アクセル/ ブレーキ操作量 $(y$ : アクセル操作量を正, ブレーキ操作量 を負として一次元化）を表す。ここで，KdB とは文献(27) で提案されている接近度に対する評価指標の一つで，運転 者の網膜上に映る前方車背面の面積の時間変化率を表す。 詳細は文献を参照されたい。また本研究では, 前方車追従 行動に㧍ける運転モードが4つに分けられるとし，その各 モードに扔ける動作の定義を次式のように異なる ARX モ デルで表現する。ここで，モード名の横にある括弧書きの ラベルは, 得られたモード分割結果に対して適切と思われる 表現を当てはめたものである。ただし，following control I と II は車間距離の違い（I：車間距離大, II：車間距離小) で区別した。

Mode A (collision avoidance)

$$
y_{k}=a_{1} x_{1, k-1}+b_{1} x_{2, k-1}+c_{1} x_{3, k-1}+d_{1} y_{k-1} \quad \text { if } x_{k-1} \in C_{1}
$$

\section{Mode B (approaching)}

$$
y_{k}=a_{2} x_{1, k-1}+b_{2} x_{2, k-1}+c_{2} x_{3, k-1}+d_{2} y_{k-1} \quad \text { if } x_{k-1} \in C_{2}
$$

Mode C (following control I)

$$
y_{k}=a_{3} x_{1, k-1}+b_{3} x_{2, k-1}+c_{3} x_{3, k-1}+d_{3} y_{k-1} \quad \text { if } x_{k-1} \in C_{3}
$$




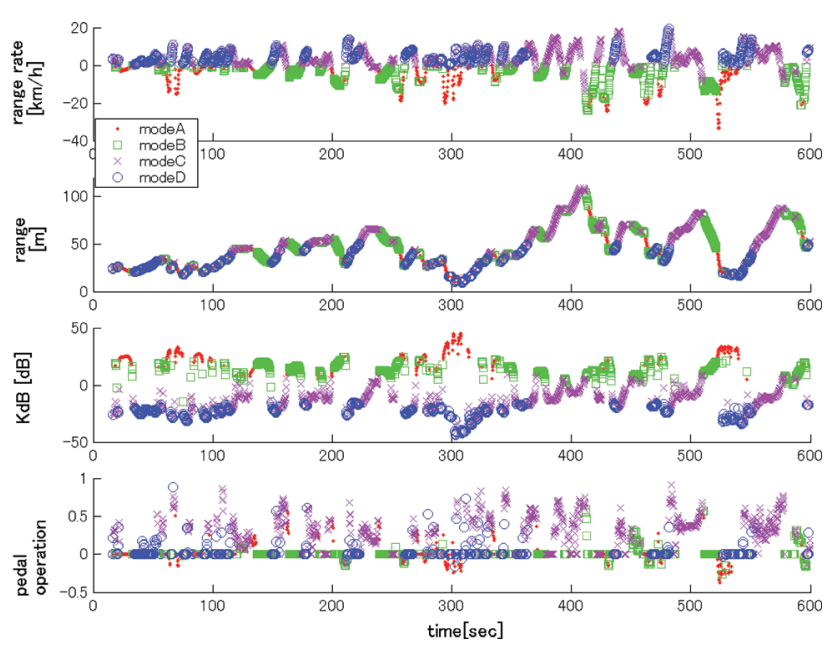

図 4 前方車追従行動における観測データ

Fig. 4. Measured data profile of vehicle following behavior.

$\underline{\text { Mode D (following control II) }}$

$$
y_{k}=a_{4} x_{1, k-1}+b_{4} x_{2, k-1}+c_{4} x_{3, k-1}+d_{4} y_{k-1} \quad \text { if } x_{k-1} \in C_{4}
$$

ここで添え字の $k$ はサンプリング時刻を表す。今，

$$
\begin{aligned}
& \psi_{k}=\left(x_{1, k-1}, x_{2, k-1}, x_{3, k-1}, y_{k-1}\right)^{T} \ldots \ldots \ldots \ldots \ldots \\
& \theta_{i}=\left(a_{i}, b_{i}, c_{i}, d_{i}\right)^{T} \ldots \ldots \ldots \ldots \ldots \ldots \ldots \ldots \ldots
\end{aligned}
$$

と定義することで，〈3・1〉節で述べたデータクラスタリン グをベースとしたハイブリッドシステムのパラメータ推定 手法が適用できる。これにより観測データのモード分割を 行った結果を図 5 に示す。図 5 は車間距離一車間相対速度 の空間でモード分割結果を示している。また，図 4 に示す 観測データにはこのように得られたモード分割結果が示し てある。

これらを見ると，4つのモードの特徽を垣間見ることが できるばかりか, SVM 等を適用してモード間の分離面を求 めることでモード間の遷移条件も導出可能となる。得られ たパラメータの詳細についてはここでは省略するが，モー ド間の分離面に現れるパラメータを調べた結果，モード間 の遷移において最も本質的な役割を果たしている知覚情報 が KdBであることが明らかとなった (7)。以上により，前方 車追従行動のハイブリッドシステムとしてのモデル化が可 能となった。

次にこの分割結果に基づて，モード間の遷移を計測し， 遷移確率を求めた結果を図 6 に示す。ただし，ここではモー ド遷移を「運転者の制御動作による遷移」と「環境（前方 車) の変化による遷移」とに分けて考え，両者の違いは操作 量 $y$ の変化率に閾值を設けることで識別した。図 6 におい て，各アークに割り当てられている $p_{1} \mid p_{2}$ はそれぞれ「運 転者の制御動作による遷移」と「環境（前方車）の変化に よる遷移」の確率を表す。また，下線付きの太数字は確率 值の高い遷移を表す。この遷移図とモード間の遷移条件を

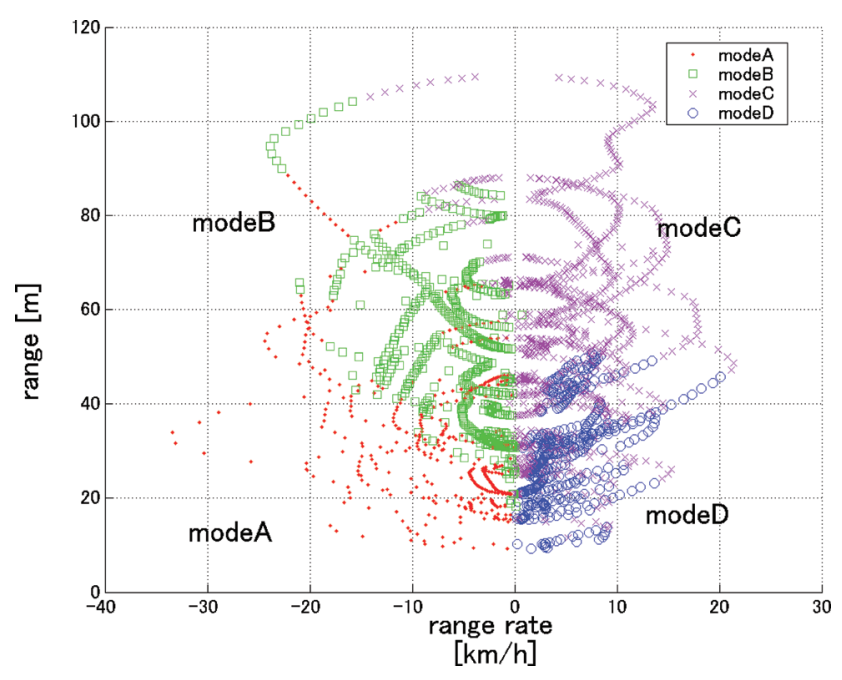

図 5 前方車追従行動のモード分割結果

Fig. 5. Mode segmentation of the vehicle following behavior.

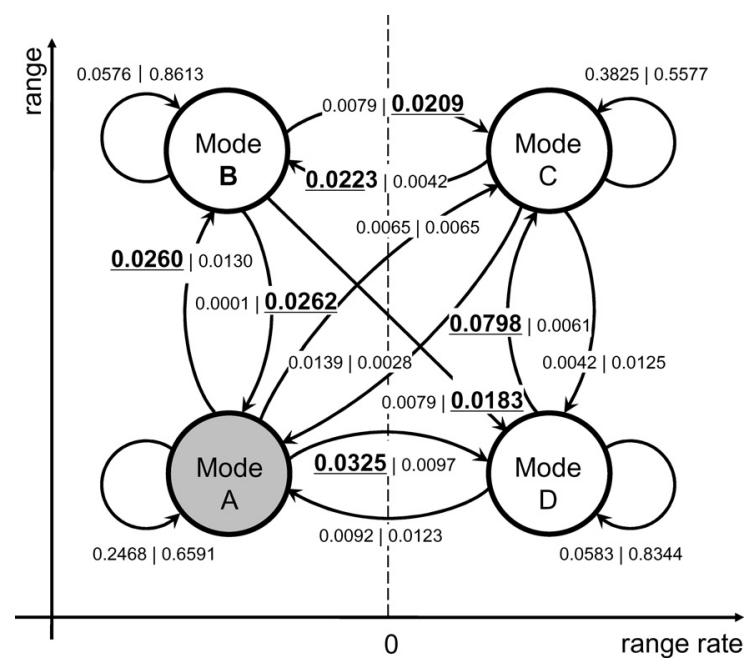

図 6 前方車追従行動の状態遷移図

Fig. 6. State transition diagram of the vehicle following behavior.

組み合わせることで前方車追従行動の高次レベルでの制御 戦略を把握することができる。また，安全性の観点からは， モード A に長い間停留しないことが重要であるため，その ようなアシストを実現する際の指針を得ることができる。

\section{5. 確率的ハイブリッドシステムモデルに基づく ペグ挿入作業のモデル化}

本章では，人間の高度なスキルの一例として，ペグの挿 入作業を取り上げ，確率的ハイブリッドシステムに基づい たモデル化について論じる ${ }^{(8)}$ 。今，図 7 に示すようなぺグ 挿入作業を考える。ここで，図中の番号は接触状態から予 想されるモードを表しており（ただし，モードの切り替え 時刻は正確にはわからないとする)，各モードでは異なる 


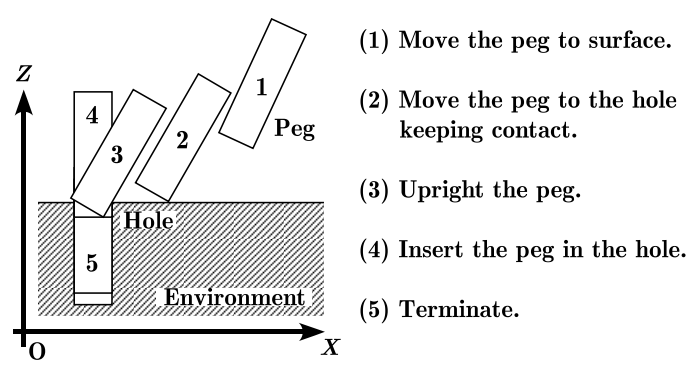

図 7 ペグの扦入作業の概略

Fig. 7. Outline of peg-in-hole task.

インピーダンス制御が実行されていると仮定する。ここで は，紙面の都合上，特に $y$ 軸周り（座標 $\rho$ で表現する）の インピーダンス制御モデルについてのみ以下に示すが，他 の座標軸に抢けるモデルについても同様に導ける。各モー ドの $y$ 軸周りのインピーダンスモデルが次式で与えられる とする。

$$
m=M_{i} \ddot{\rho}+C_{i} \dot{\rho}+K_{i} \rho+D_{i} .
$$

ここで， $M_{i}, C_{i}, K_{i}, D_{i}$ はそれぞれ，インピーダンスモデ ル中の慣性項, 粘性項, 剛性項, オフセット項を表す。ま た， $m$ はぺグに加わる $y$ 軸周りのモーメントを表す。さら に，連続時間系のパラメータをそのまま保存した離散時間 モデルを得ることが可能となるフィルタリング(28)を入出力 信号 $(\rho$ と $m)$ に施すことによって, 次式のような PWARX モデルによる表現を得る。

$$
\begin{aligned}
m_{F, k} & =M_{i} \rho_{F 0, k}+C_{i} \rho_{F 1, k}+K_{i} \rho_{F 2, k}+D_{i} d_{F, k}+e_{i, k} \\
& =\boldsymbol{\psi}_{k}^{T} \boldsymbol{\theta}_{i}+e_{i, k} \ldots \ldots \ldots \ldots \ldots \ldots \ldots \ldots \ldots
\end{aligned}
$$

ここで,

$$
\begin{aligned}
& \boldsymbol{\theta}_{i}=\left(M_{i}, C_{i}, K_{i}, D_{i}\right)^{T}, \ldots \ldots \\
& \boldsymbol{\psi}_{k}=\left(\rho_{F 2, k}, \rho_{F 1, k}, \rho_{F 0, k}, d_{F, k}\right)^{T}
\end{aligned}
$$

である。なお，フィルタリングの詳細については文献を参 照いただきたい。また，離散構造としては 5 状態の left-toright 型のモデルを考える。各離散状態（モード）にはそれ ぞれ異なるインピーダンスモデルが割り当てられている。

以上の準備のもと，被験者にペグ挿入作業を実行しても らい,〈3・2〉節で示したパラメー夕推定法を用いて各モー ドのインピーダンスモデルと切り替え（モード遷移）時刻 を推定した。紙面の都合上，得られたパラメー夕は省略す るが, 図 8 に推定したパラメータと切り替え時刻を用いて 再現した $y$ 軸周りのモーメントと観測されたモーメントを 示す。これを見ると両者はよく一致しており，5モードの インピーダンス制御でモデル化することの妥当性が見てと れる。また，同図には，推定した切り替え時刻とそのとき のペグと環境の接触状態が示してある。これを見ると，接 触状態変化にほぼ対応したモード遷移が推定できているこ とがわかる。これょり，被験者は接触状態に応じて適切に

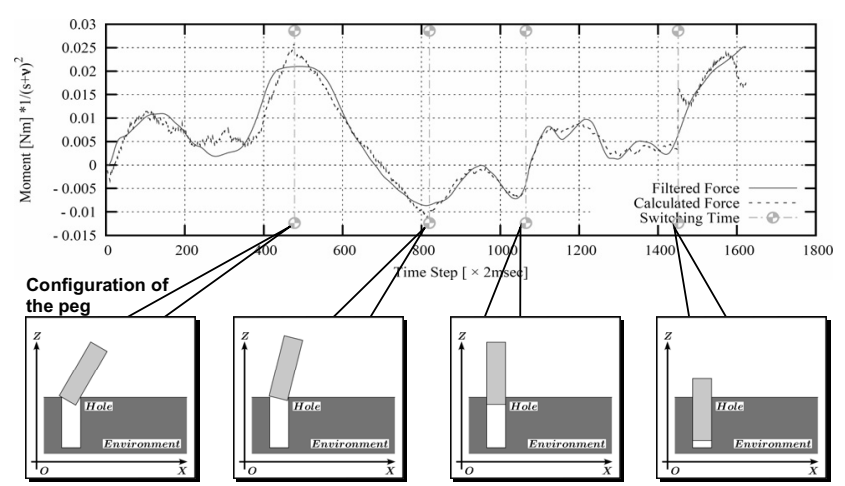

図 8 ペグ挿入作業の同定とモード分割結果

Fig. 8. Identification of the peg-in-hole task and obtained mode segmentation.

インピーダンスパラメータを切り替えながら作業を行って いることが明らかとなったが，このように連続的な制御則 とその切り替え戦略とで高度なスキルをモデル化できる点 がハイブリッドシステムとして捉える利点であると言える。 また，音声認識の分野で HMM が大きな成功を収めたこと からもわかるように，確率的なハイブリッドシステムモデ ルの有力な応用先の一つとして, モデルに基づく行動認識 が挙げられる(9)。未知の行動デー夕が観測された際にその データのモデルに対する尤度を計算することで，一種の行 動認識が可能となり，バイオメトリクス等様々な分野での 応用が期待できる。

\section{6. 記号接地問題とハイブリッドシステム}

エキスパートシステムに代表される記号処理的な AI に おいて, 記号接地の問題，すなわち記号化された表現と実世 界での現象をどのように関連付けるかは大きな課題となっ ている。この点が克服されない限り記号処理的な $\mathrm{AI} に は$ 限界があると思われる。本論文で述べたハイブリッドシス テムモデルをべースとした現象の表現，モデル化手法は，実 世界に扔ける現象からほぼ自動的に記号化された表現を抽 出することができる一種の信号一記号変換との見方もでき る。その意味では, 記号処理的な AIにおける記号接地問 題の有力な解決手法の一つとなり得ると考えられる。

また，上位概念としての記号処理的な AI と融合するこ とで, 実世界との親和性が高い知的人工システムの構築に つながると期待できる。

\section{7. まとめ}

本論文では，確定的／確率的なハイブリッドシステムモ デルに基づいた高次モーションの解析・設計のための新た な枠組みを提案し, 具体例を交えてその有用性, 可能性につ いて論じた。確定的なモデルは，動作と判断の両側面を明 示的に同時に表現しているという点で, 今後必要となる各 種の高次モーション支援系の設計に重要な情報を与えてく れると期待できる。また，確率的なモデルは，行動情報に 
よるバイオメトリクス等，行動の認識や識別問題において 重要な役割を果たすと考えられる。さらには，ハイブリッ ドシステムモデルに基づく行動解析そのものが, 記号処理 的 AI における記号接地問題解決の有力な方法論になると 期待される。ハイブリッドシステム研究のそもそもの動機 付けが，計算機科学と制御工学との融合にあったことから， 多角的な視点が必要とされる人間の高次モーションをハイ ブリッドシステムとして捉える試みは極めて自然であると 考えられる。また本論文では, 主にパラメータ推定の視点 からハイブリッドシステムと高次モーションの関係につい て述べたが，最適化の視点 ${ }^{(29)(30)}$ からこれらの関係について 検討する研究例もあり ${ }^{(31)}$, 今後の発展が期待される。いず れにしても，ハイブリッドシステムをべースとした人間行 動の解析・モデル化は，新たな数理モデルを提供する可能 性があるという点において，従来の人間工学や制御工学で は得られなかった新たなブレークスルーをもたらしてくれ る可能性を秘めていると言える。

(平成 19 年 7 月 27 日受付，平成 19 年 10 月 19 日再受付)

\section{文献}

（1）「特集：ハイブリッドシステムの最前線」, 計測と制御, Vol.44, No.7 (2005)

（2）鈴木達也:「ハイブリッドシステムモデルに基づく行動情報処理」,計 測と制御, Vol.44, No.7, pp.452-457 (2005)

（3）鈴木達也・井村順一:「ハイブリッドシステムとして捉える人間行 動モデル」,計測と制御, Vol.45, No.12, pp.1055-1061 (2006)

（4）高崎秀明・稲垣伸吉・鈴木達也：「確率的切り替えを伴う動的モデ ルに基づく歩行動作の解析」, 計測自動制御学会 SI 部門学術講演会, pp.99-100 (2005)

(5) J.H. Kim, S. Hayakawa, T. Suzuki, K. Hayashi, S. Okuma, N. Tsuchida, M Shimizu, and S. Kido: "Modeling of Driver's Collision Avoidance Maneuver based on Controller Switching Model", IEEE Trans. on System, Man and Cybernetics, part B, Vol.35, No.6, pp.1131-1143 (2005)

（6）山田・鈴木達也・稻垣伸吉・早川・土田・津田・藤波：「ハイブリッ ドシステムモデルに基づく運転行動解析一データクラスタリング手 法からのアプローチー」, 日本人間工学会誌, Vol.42, No.3, pp.181-189 (2006)

(7) T. Akita, S. Inagaki, T. Suzuki, S. Hayakawa, and N. Tsuchida: "Analysis of Vehicle Following Behavior of Human Driver Based on Hybrid Dynamical System Model", Proc. of IEEE Multi-conference on Systems and Control, pp.1233-1238 (2007)

(8) T. Suzuki, S. Inagaki, and N. Yamada: "Human Skill Modeling based on Stochastic Switched Dynamics", Proc. of the IFAC Conf. on Analysis and Design of Hybrid Systems, pp.64-70 (2006)

(9) S. Sekizawa, S. Inagaki, T. Suzuki, S. Hayakawa, N. Tsuchida, T. Tsuda, and H. Fujinami: "Modeling and Recognition of Drivng Behavior Based on Stochastic Switched ARX Model", IEEE Trans. on Intelligent Transportation Systems (2007) (to appear)

(10) F.A. Mussa-Ivaldi, S.F. Giszter, and E. Bizzi: "Linear Combinations of Primitives in Vertebrate motor control", Proc. of the National Academy of Science, 91, pp.7534-7538 (1994)

(11) E.E. Bizzi and F.A. Mussa-Ivaldi: "Toward a neurobiology of coordinate transformations", The New Cognitive Neurosciences, Second Edition Cambridge, MA: MIT Press, pp.489-500 (1999)

(12) C. Bregler and J. Malik: "Learning and recognizing human dynamics in video sequences", Proc. of IEEE Conf. on Computer Vision and Pattern Recognition, pp.568-674 (1997)

(13) L. Goncalves, E.D. Bernardo, and P. Perona: "Reach out and touch space (motion learning)", Proc. of Third Inter. Conf. on Automatic Face and Gesture Recognition, pp.234-239 (1998)

(14) D.D. Vecchio, R.M. Murray, and P. Perona: "Decomposition of human motion into dynamics-based primitives with application to drawing tasks", $\mathrm{Au}$ tomatica, Vol.39, pp.2085-2098 (2003)
(15) T. Roll, A. Bemporad, and L. Ljung: "Identification of piecewise affine systems via mixed-integer programming", Automatica, Vol.40, pp.37-50 (2004)

(16) A. Bemporad, A. Garulli, S. Paoletti, and A. Vicino: "A greedy approach to identification of piecewise affine models", Hybrid Systems - Computation and control LNCS 2643, pp.97-112 (2003)

(17) G. Ferrari, M. Muselli, D. Liberati, and M. Morari: "A clustering technique for the identification of piecewise affine systems", Automatica, vol.39, pp.205-217 (2003)

18) R. Vidal, S. Soatto, Y. Ma, and S. Sastry: "An Algebraic Geometric Approach to the Identification of a Class of Linear Hybrid Systems", Proc. of the IEEE Conf. on Decision and Control, pp.167-172 (2003)

19) A.L. Juloski, S. Weiland, and W.P.M.H. Heemels: "A Bayesian Approach to Identification of Hybrid Systems", Proc. of the IEEE Conf. on Decision and Control, pp.13-18 (2004)

20) L.R. Rabiner: "A Tutorial on Hidden Markov Models and Selected Applications in Speech Recognition", Proceedings of the IEEE, Vol.77, No.2, pp.257-285 (1989)

(21) H. Balakrishnan, I. Hwang, J.S. Jang, and C.J. Tomlin: "Inference Methods for Autonomous Stochastic Linear Hybrid Systems", Hybrid Systems Computation and control LNCS 2993, pp.64-79 (2004)

（22）山田直幸・鈴木達也・稲垣伸吉：「確率的切り替えを伴う ARX モデル のパラメータ推定」,計測自動制御学会論文集, Vol.41, No.9, pp.754-762 (2005)

(23) D. McRuer and D. Weir: "Theory of manual vehicular control", Ergonomics, Vol.12, pp.599-633 (1969)

(24) A. Modjtahedzadeh and R. Hess: "A Model of Driver Steering Control Behavior for Use in Assesing Vehicle Handling Qualities", ASME J. of Dynam. Syst. Meas. Contr., Vol.15, Sept., pp.456-464 (1993)

(25) C. MacAdam: "Application of an optimal preview control for simulation of closed-loop automobile driving", IEEE Trans. on Syst. Man and Cyber., Vol.11, No.9, pp.393-399 (1981)

２6）鈴木達也：「運転におけるヒューマンファクターの解析〜 コントロー ラとしてのドライバ〜」,計測と制御, Vol.45, No.3, pp.231-236 (2006)

(27) T. Wada, S. Doi, K. Imai, N. Tsuru, K. Isaji, and H. Kaneko: "Analysis of Drivers' Behaviors in Car Following Based on A Performance Index for Approach and Alienation", SAE paper 2007-01-0440, Proc. of SAE2007 World Congress

(28) S. Sagara, Z.J. Yang, and K. Wada: "Identification of Continuous Systems Using Digital Low-pass Filters", Int.J. Syst. Sci., Vol.22, No.7, pp.11591176 (1991)

(29) Y. Wada, Y. Koike, E.V.Bateson, and M. Kawato: "A Computational Theory for Movement Pattern Recognition based on the Optimal Movement Pattern Generation", Biological Cybernetics, Vol.73, pp.15-25 (1995)

３0）井村順一:「ハイブリッドシステムのリアルタイム最適制御」, 計測 と制御, Vol.44, No.7, pp.464-470 (2005)

（31）田崎勇一・井村順一：「平面 2 足歩行ロボットのグラフ型モデル予 測制御」,日本ロボット学会誌, Vol.24, No.5, pp.663-671 (2006)

鈴 木 達 也 (正員) 1964 年 1 月 3 日生。1991 年名古屋大学

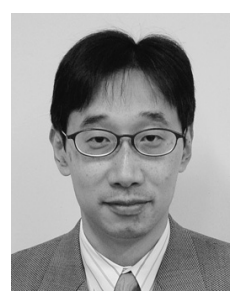
大学院博士課程後期課程電子機械工学専攻修了。 工学博士。同年名古屋大学工学部助手。2000 年 同助教授。2006 年同教授。現在に至る。この間, 1998 年から 1 年間, U.C.Berkeley 客員研究員。八 イブリッドシステム論に基づくディペンダブルシ ステムの設計・実現や人間行動の解析とその人間 機械系への応用等に関する研究に従事。1995 年 電気学会論文賞, 2004 年 SICE システム情報部門学術講演会論文賞な どを受賞。計測自動制御学会, 電子情報通信学会, 日本機械学会, シ ステム制御情報学会, 日本ロボット学会, 日本人間工学会, IEEE の 各会員。 